\title{
Analysis of Online Learning Evaluation of Social Science Education Study Program
}

\author{
Asep Ginanjar ${ }^{1}$, Noviani Achmad Putri ${ }^{2}$, Heri Setyawan ${ }^{3}$, Afif Abdan Shakuro ${ }^{4}$, \\ Farida Nur Aini ${ }^{5}$, Risnanda Fermansyah ${ }^{6}$ \\ ${ }^{12456}$ Faculty of Social Sciences, Universitas Negeri Semarang \\ ${ }^{3} 19$ Balikapapan Junior High Schools \\ \{asep.ginanjar@mail.unnes.ac.id ${ }^{1}$, noviani.ips@mail.unnes.ac.id ${ }^{2}$, herisetyawan.indonesia@ gmail.com ${ }^{3}$, \\ afifabdan@students.unnes.ac.id ${ }^{4}$, faridanuraini@students.unnes.ac.id ${ }^{5}$, rinandafermansyah@ students.unnes.ac.id $\left.{ }^{6}\right\}$
}

\begin{abstract}
Social Science Education Program as the most recent study program in the Faculty of Social Sciences with limited infrastructure and human resources, of course, online learning is a challenge, especially when new students in 2020 must immediately feel online learning where students still do not understand how the atmosphere of learning at the university level. The purpose of this study is to analyze the implementation of online learning in the Social Science Education Program in 2020/2021, to know the obstacles in online learning in the Social Science Education Program in 2020/2021, and to know students' perception of online learning in the Social Science Education Program in 2020/2021. The research method used in this research is qualitative research. The results of this study related to the implementation of online learning in the Social Education Program were conducted in Synchronous and Asynchronous manner. Obstacles in online learning include learning is still dominant yet interactive, student behavior is difficult to monitor, learning tends to be online assignments, the absorption of lecture materials is very limited and assessments and evaluations conducted by lecturers ranging from daily exams, midterm exams and final exams are less integrated, internet network constraints and internet quota load owned by students.
\end{abstract}

Keywords: Online Learning, Elena, Learning Management System.

\section{INTRODUCTION}

The Covid-19 pandemic makes lectures that were previously carried out by blended learning become fully online. Of course, the obstacles that have existed since the beginning of the implementation of blended learning have become increasingly widespread. This can be understood because Indonesia's infrastructure cannot support online lectures, this can be seen from the data from the International Telecommunication Union (ITU) (2017) showing that Indonesia is ranked 8th out of 11 countries in Southeast Asia with household internet users, and only $32.29 \%$ of Indonesia's population has internet access, ITU also noted that in 2018 only 3 people per 100 Indonesians became internet subscribers [1]. Specifically for Central Java province, based on BPS data in 2019, the percentage of households with computers in urban areas is only $22.99 \%$, in rural areas $9.83 \%$ and in sub-urban areas is $16.48 \%$ [2], this shows that There are still many Central Java residents who do not have computer facilities, especially those who live in rural areas, of course this is an obstacle in the online learning process.

The Social Science Education Study Program as the youngest study program in the Faculty of Social Sciences with limited infrastructure and human resources, of course, online learning is a challenge in itself, especially when 2020 students who enter the world of campus from the start must immediately experience online learning where students this generation still does not really understand how the learning atmosphere in tertiary institutions is. This of course requires more effort to create effective and efficient online learning. Based on this background, the purpose of this study is to analyze the implementation and obstacles that occur in online 
learning in the Social Science Education Study Program in the odd semester of 2020/2021.

Online learning is learning that is done without face to face and uses a specific platform so that it can be done remotely [3]. Meanwhile, according to Moore, DicksonDeane, and Galyen, online learning is learning that uses internet networks with accessibility, connectivity, flexibility, and the ability to generate various types of learning interactions [4]. When viewed from the definition, online learning has the characteristics of faceto-face learning and uses electronic devices and the internet as a medium in learning so that online learning is more accessible and flexible. Online Learning is actually an evolution of distance learning, as a result of the development of communication and information technology.

In the online learning process, it is necessary to apply the learning theory of behaviorism, cognitivism, constructivism, and conectivism. Online learning in the principles of behaviorism, every learning process must display learning objectives, the achievement of the learning process must be assessed, and there is feedback given by the lecturer to students.

The principle of the learning theory of cognitivism states that learning is an information processing process characterized by cognitive changes in students so that in each learning the material presented must be gradual so that it is easy to understand, the presentation of the material uses a variety of media so that it can accommodate various student learning styles, as well as measurement learning outcomes as a sign of the learning process.

The principle of constructivism learning theory states that learning is a construction of meaning that is obtained from various interactions both individually and socially, so that in each learning process must present material interactively, there are examples and meaningful exercises, students learn independently, and there is a means of interaction for both individuals and social in the learning process.

The principles of conectivism learning theory emerged as a result of the massive and rapid development of science so that learning activities in the digital era were increasingly complex. In this theory, the learning process is the formation of knowledge network connections, so that in the learning process it is an activity to connect various kinds of entities, develop connections to facilitate learning continuity, develop the ability to identify and make connections between fields, ideas and concepts, develop lifelong learning abilities, and develop the ability to make decisions.

Online learning can be categorized into two types, namely (1). Independent learning, where the learning process is initiated by students within a certain period. Lecturers prepare various tasks and triggers in online learning; (2). Guided / structured learning, where the learning process is in the form of face-to-face tutorials in the form of direct guidance or through minimal virtual meetings, and online tutorials in the form of lecturer interactions with students through ICT-based media such as chat, email, blogs, social media, or LMS both synchronous and asynchronous. Ideally there are five aspects of the online learning process that influence each other, these five aspects are: learning design, learning activities, delivery strategies, learning media and technology, learning assistance services [5].

\section{RESEARCH METHOD}

The research method used in this research is qualitative research. This research method is in the form of descriptive data that does not use numbers to explain the research results. The selection of qualitative research methods was based on the main objectives of the study, namely to analyze and describe online learning in the Social Science Education Study Program, Faculty of Social Science UNNES. This research is located in the Social Science Education Study Program, Faculty of Social Sciences, Universitas Negeri Semarang, with the research focus is to analyze the implementation and obstacles that occur in online learning in the Social Science Education Study Program in the odd semester of 2020/2021.

In this study, the primary data sources came from the main informants and supporting informants which included lecturers and students of the 2020 class of Social Science Education Study Program, which was carried out through interviews with snowball throwing techniques. Secondary data in this study which serves as a complement and support for primary data, namely in the form of library sources, supporting articles, and semester lesson plan. The data in this study were obtained through in-depth interviews and documentation

The data analysis method in this research is interactive analysis with steps including data presentation, data reduction, data presentation, drawing conclusions or verification [6]. The validity test technique in this study uses triangulation, by combining two triangulation techniques, namely triangulation of sources with triangulation of methods.

\section{RESULTS AND DISCUSSION}

Prior to the pandemic, in accordance with the policies of the University and the faculty, lectures in the Social Science Education Study Program had implemented blended learning with a proportion of $60-70 \%$ face-toface and $30-40 \%$ carried out using the UNNES special Learning Management System, namely elena so that in 
terms of facilities and infrastructure and human resources those who master technology in terms of online learning in the Social Science Education Study Program are quite ready. Online learning in the Social Science Education Study Program is carried out synchronously and asynchronously by utilizing various platforms such as Zoom, Google Meet, Whatsapp, Telegram, and Elena.

The use of Zoom and Google Meet is used when learning is carried out synchronously, each study program in the Faculty of Social Sciences is provided with Zoom licensed with a capacity of 300 people, by only having one Zoom account that is licensed, this causes lectures to be carried out synchronously, having to make slight adjustments to avoid schedule mash. Apart from Zoom, each lecturer has an email which is also a Google Suite account, the result of the collaboration between the University and Google, so that they have more access to services provided by Google, including Google Meet and Google Classroom. Figure 1 shows a lecture carried out synchronously using Zoom.

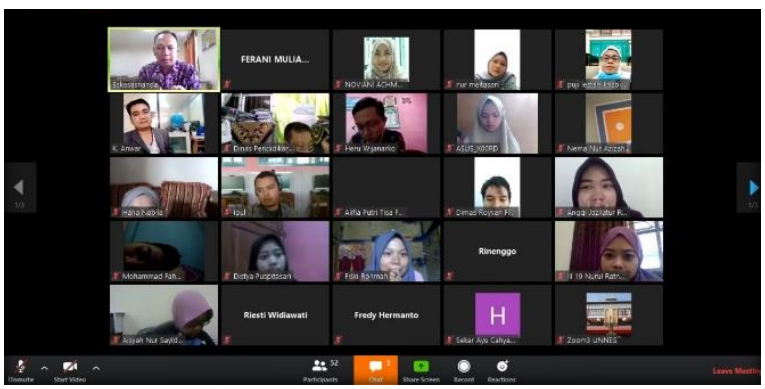

Fig. 1. Lectures Synchronously Using Zoom

Asynchronous lectures are carried out using Elena in which there are already available teaching materials that have been prepared by each team of lecturers. In this elena, apart from teaching materials, lecturers can also provide various kinds of learning resources or media in the form of pictures or videos, quizzes, assignments, discussion forums, attendance can also be done in elena. Figure 2 shows an example of the appearance of elena in the Basics of Geography Course.

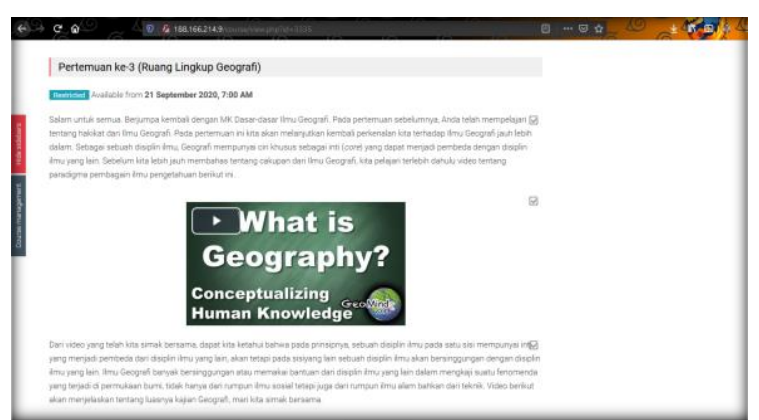

Fig. 2. Elena's Display in One of the Subjects

Whatsapp and Telegram applications are used for communication or coordination related to lectures and assignments between lecturers and students. Especially for the telegram application, lecturers can broadcast to all students in certain courses and classes. Also on telegram, lecturers receive notification of lecture schedules and attendance validations that have been carried out by students. An example of a broadcast carried out by a lecturer to the class in the Social Science Education Philosophy course can be seen in Figure 3.

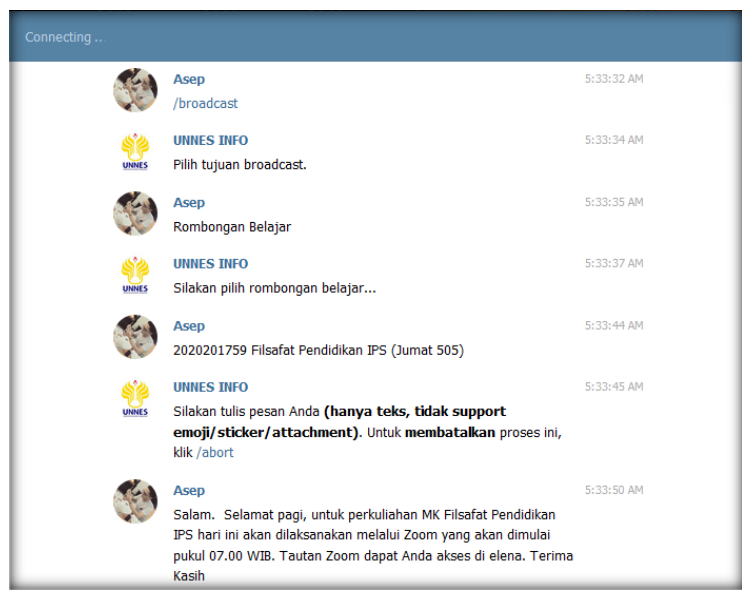

Fig. 3. Broadcast conducted by lecturers through the telegram application

Lecturers and students also create groups on the Telegram or Whatsapp application. This group is often used for discussions, announcements or assignments which are considered more effective if done through elena. In Figure 4, you can see an example of the Whatsapp group in the Social Science Education Philosophy course.

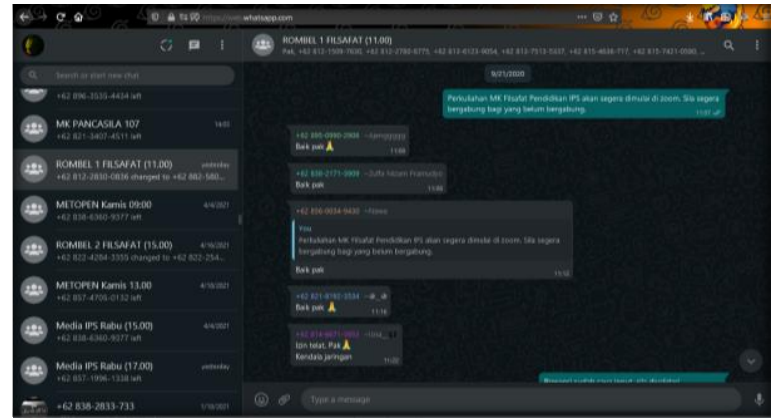

Fig. 4. Group of One of the Subjects in the Social Science Education Study Program

Especially for the 2020 class who just entered lectures during the pandemic, the Social Science Education Study Program provides debriefing regarding the introduction of systems in the campus environment, so that new students can take part in technical lectures that they are doing for the first time. Even so, in practice there are still many new students who have difficulty using the systems on campus, this makes in the first week of lectures, many lecturers have to provide guidance via Whatsapp related to lecture techniques so the lecture process is not optimal. Figure 5 shows some of the systems on the apps.unnes.ac.id page. 


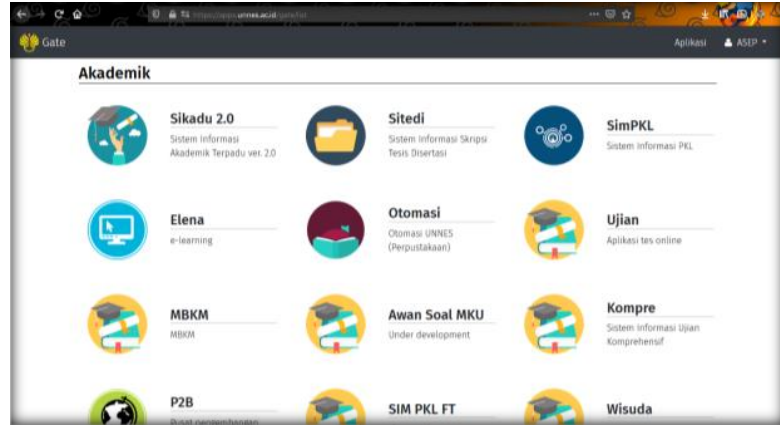

Fig. 5. Display Menu from apps.unnes.ac.id

Another obstacle that arises when lecturing online is the uneven signal in student residences which causes many students to experience difficulties when lectures are carried out synchronously which demands stable signal strength. The limited student quota is also an obstacle in online lectures, even though there is a quota assistance from the Ministry of Education and Culture, but there are several pages on the internet that are used as learning resources that cannot be accessed by using the quota from the Ministry of Education and Culture. In addition, there are still some students who do not have or take turns using the devices needed in online lectures, there are still many students who use their devices alternately with their siblings who are both learning from home, this of course causes the lecture of students to be hampered, both during college and while working on assignments given by the lecturer.

In addition to the constraints in terms of facilities and infrastructure, the most influential obstacle is the low level of motivation of some students, there are still those who do lectures asynchronously, just opening elena, then presence after that carry out activities that are not related to lectures, as well as during lectures synchronously through Zoom and Google Meet, there are still students who just log in then turn off the camera and microphone then do activities outside of lectures, this can be seen when lectures are over, many students don't leave the virtual meeting room for a long time. This indicates that they did not listen to the content of the lecture.

Furthermore, the obstacle encountered in online lectures in the Social Science Education Study Program is the limited mastery of technology by lecturers. It cannot be denied that with the suddenness of lectures being carried out fully online, many lecturers conduct lectures by ,learning by doing', this of course causes online lectures to not run optimally.

Another thing that was found was that there were several advantages of lectures being carried out online such as flexible time where students and lecturers could study anytime and anywhere, then learning resources were increasingly numerous and varied, with the implementation of online lectures forcing lecturers to design attractive and attractive teaching materials. can make students learn independently, this makes lecturers look for teaching materials from various sources in the form of self-made videos or using existing videos, links to various kinds of scientific journals, as well as LMS that are widely available on the internet such as Ruang Belajar from the Ministry of Education and Culture, Kahoot , and quizleet. This can indirectly increase digital literacy which is very much needed in the era of the industrial revolution 4.0 because online learning makes students search for and obtain information from digital content in a wider scope. Online lectures can encourage students to have the skills needed as global citizens which include 1) digital age literacy, which includes (a) basic, scientific and technological literacy, (b) visual and information literacy, and (c) cultural literacy and global awareness; 2) thinking inventive-intellectual capital, which includes (a) adaptability / managing complexity and independence (self-direction), (b) curiosity, creativity and courage to take risks, (c) thinking in a higher order and reasoning; 3) interactive communication-social and personal skills, which include (a) working in groups, and working together (collaboration), (b) personal responsibility, and social, (c) interactive communication; 4) quality and up-to-date results, which include (a) prioritizing, planning, and managing results, (b) using real-world tools effectively, (c) high-quality results with real-world application [7].

In online lectures, it was found that students tended to be more courageous to ask questions and express their opinions compared to face-to-face lectures. Many students during face-to-face lectures tend to be passive, but when discussing in discussion forums they tend to be active in expressing opinions and are more willing to ask questions when lectures are carried out synchronously through virtual meetings. This is in line with the four basic social skills skills, namely (1) Social Skills which include cooperation, helping, controlling and controlling oneself towards others, as well as counseling with others; (2) Study Skills and Work Habit, which includes gathering information from various sources, compiling reports, speaking in groups and with the general public, reading various social studies sources, collecting and classifying data; (3) Group Work Skills, which includes participating in group discussions and making group decisions; the last (4) Intellectual Skills which include exploring and formulating problems, compiling and testing hypotheses, analyzing and synthesizing data, listening to cause-and-effect relationships, and comparing and contradicting various opinions or views [8].

In addition to the advantages of online lectures, this study also found that there are shortcomings of online lectures such as lecture material which is a lot of assignments so that it adds to the burden of students, the difficulty of supervising student behavior when the lecture process is in progress, the difficulty of delivering material, especially in subjects in the form of practicum, students find it difficult to focus because studying from 
home there are many factors that can distract students such as weak signals, environmental conditions that do not support students to focus on learning. Frequent lecture schedules that move suddenly. Then the last thing is the difficulty of conducting a comprehensive assessment because of the limited interaction between lecturers and students.

\section{CONCLUSION}

Based on the results of the analysis of the implementation of online lectures in the Social Science Education Study Program, it is known that the implementation of online lectures is carried out synchronously and asynchronously by using elena and other digital platforms. There are several obstacles during the implementation of online lectures which include infrastructure constraints such as uneven signal, limited student quota, and limited ownership of devices that support online lectures. Constraints are also found in the lack of student motivation to learn and the limited mastery of digital technology by lecturers. Another thing that is the finding of this research is that there are advantages of online lectures, namely flexible time, students tend to be more courageous to answer and ask questions, the number of digital learning resources. The weaknesses of online lectures are the large amount of material in the form of assignments, the difficulty of monitoring student behavior, the difficulty of online lectures from courses in the form of practicum, lecture schedules that often move, students have difficulty focusing, and the difficulty of conducting thorough assessments.

Based on the conclusions above, the suggestions that can be given are: The implementation of learning does not have to be fully online but can be supported by a mechanism for providing learning activity packages, namely materials and assignments that can be given directly to students for the next one or two weeks. Collaboration between teaching teams is needed both in terms of material processing and mastery of technology and the need for operators to assist in the implementation of online learning. Practical subjects should be carried out using two models, namely the theory part is delivered online, and the practice is carried out offline with limited participants. It is necessary to design innovative, creative and communicative online learning so that student motivation in participating in learning can be maintained. It is necessary to design an authentic and comprehensive assessment starting from the cognitive aspect by giving assignments, affective assessment with attitude journals as well as assessing the skills aspect with the video call/offline method.

\section{AUTHORS' CONTRIBUTIONS}

The first author's contribution: Analyzing the results of data collection related to the technicalities and advantages of implementing online learning in the Department of Social Science Education; Second author: Analyzing the results of data collection related to the weaknesses and obstacles in the implementation of online learning in the affairs of Social Science Education. Third, fourth, fifth and sixth authors: Conducting data collection in the field related to the implementation of online learning; Contribution of all teams: Processing and compiling the results of research analysis into writing this article.

\section{ACKNOWLEDGMENT}

The author would like to thank students and lecturers of the Social Science Education Study Program who have been willing to become sources in this research. The author also thanks reviewers who have provided meaningful input for improving the writing of this article.

\section{REFERENCES}

[1] https://news.detik.com/kolom/d-5059820/pandemidan-pemerataan-infrastruktur-telekomunikasi

[2] Sub Direktorat Statistik Komunikasi dan Teknologi Informasi (Sub-Directorate of Communication Statistics and Information Technology).: Statistik Telekomunikasi Indonesia 2019 (Indonesia Telecommunications Statistics 2019). Jakarta: Badan Pusat Statistik (Central Bureau of Statistics), pp. 2931 (2019)

[3] Sofyana and Abdul.: Pembelajaran Daring Kombinaasi Berbasis Whatsapp pada Kelas Karyawan Prodi Teknik Informatika Universitas PGRI Madiun (Whatsapp-Based Combinatorial Online Learning in the Employee Class of Informatics Engineering Study Program, Madiun PGRI University). Jurnal Nasional Pendidikan Teknik Informatika, pp. 81-86 (2019)

[4] Moore, J. L., Dickson-Deane, C., and Galyen, K.: E Learning, Online Learning, and Distance Learning Environments: Are They the Same?. Internet and higher Education https://doi.org/10.1016/jiheduc.2010.10.001. (2011)

[5] ___ . Panduan Penjaminan Mutu Proses Pembelajaran Daring. Jakarta: Direktorat Pembelajaran dan Kemahasiswaan Direktorat Jenderal Pendidikan Tinggi Kementerian Pendidikan dan Kebudayaan, pp. 10-14. (2014)

[6] Miles, Matthew B and A Michael Huberman.: Analisis Data Kualitatif. Translated by Tjetjep Rohendi Rohidi. Jakarta: UI PRESS, pp. 19. (1992)

[7] www.metiri.com.

[8] Jarolimek, J.: Social Studies Competencies and Skill. New York: McMillan. (1977). 